\title{
Persepsi Guru Madrasah Ibtidaiyah terhadap Pembelajaran Daring Selama Program Belajar dari Rumah (BDR) di Masa Pandemi COVID-19
}

\author{
Ahmad Syamsul Arifin, Sukati \\ Pendidikan Guru Madrasah Ibtidaiyah, FAI, Universitas Alma Ata \\ e-mail: a.syamsul_arifin@almaata.ac.id. \\ sukati@almaata.ac.id
}

\begin{abstract}
Abstrak
Pandemi Covid-19 telah menyebabkan sejumlah institusi pendidikan di Indonesia ditutup untuk sementara waktu. Kegiatan pembelajaran di sejumlah zona wilayah dilaksanakan melaui mode daring (dalam jaringan) dan meniadakan pembelajaran tatap muka atau luar jaringan (luring). Implementasi pembelajaran daring di Indonesia, termasuk di kabupaten Bantul DIY, bukan merupakan perkara mudah karena hal ini menjadi bagian untuk beradaptasi dengan kebiasaan baru di dunia Pendidikan Indonesia. Penelitian ini bertujuan untuk menggali persepsi guru terhadap pembelajaran daring yang telah diselenggarakan selama pandemic Covid-19 ini.

Metode penelitian yang digunakan adalah penelitian kuantitatif deskriptif untuk mengetahui gambaran persepsi guru terhadap efektivitas pembelajaran daring selama masa pandemi Covid-19 ini. Responden dalam penelitian ini adalah guru-guru MI di wilayah kabupaten Bantul sebanyak 46 orang. Teknik pengumpulan data yang digunakan yakni kuesioner atau angket yang disebarkan kepada informan melalui suvei secara daring (medsos dan surat elektronik).

Berdasarkan hasil penelitian diperoleh gambaran bahwa semua guru MI di lingkungan Kabupaten Bantul telah melaksanakan pembelajaran daring. Meskipun demikian, sebagian besar responden menyatakan bahwa pembelajaran daring ini belum berjalan secara efektif (69,60\%). Hal ini dipengaruhi oleh keterbatasan sarana-prasarana, kesiapan orang tua/ wali dalam melakukan pendampingan kepada anak pada saat belajar dari rumah, dan sebagian guru belum mampu merespon dan beradaptasi dengan mode pembelajaran daring ini secara efektif.
\end{abstract}

Kata kunci: persepsi guru, pembelajaran daring, pandemi covid-19

\begin{abstract}
The Covid-19 Pandemic has caused a number of educational institutions in Indonesia to be temporarily closed. Learning activities in a number of areas are carried out online and eliminate face-to-face learning. The implementation of online learning in Indonesia, including in Bantul DIY district, is not an easy matter because it is a new way of adapting to the new Indonesian education system. This study aims to explore teachers' perceptions of online learning that have been held during the Covid-19 pandemic.

The research method used in this research is descriptive quantitative research which aims to describe the teacher's perceptions of the effectiveness of online learning during the Covid-19 pandemic. Respondents in this study were 46 teachers. The data collection technique used was a questionnaire that was submitted to the respondents online (social media and electronic mail).

Based on the results of the study, it was found that all Islamic elementary school (Madrasah Ibtidaiyah) teachers in Bantul had implemented online learning. Even so, most of the respondents stated that online learning was not yet effective (69.60\%). This is influenced by
\end{abstract}


limited infrastructure, the readiness of parents to provide assistance to children while learning from home, and some teachers have not been able to respond and adapt to this online learning properly and effectively.

Keywords: teacher perceptions, online learning, pandemic covid-19

\section{PENDAHULUAN}

Sejak kemunculannya pada Januari lalu di kota Wuhan, Cina, terpaan pandemi corona virus desease-19 (COVID-19) telah merubah wajah dunia. Penyebaran virus yang cepat dan masif telah menimbulkan global shock di berbagai sendi kehidupan masyarakat di seluruh belahan penjuru dunia. Tidak hanya sektor kesehatan dan ekonomi yang tertkena imbasnya, tapi hampir setiap sendi kehidupan masyarakat global tidak luput dari terpaan pusaran pandemi ini.

Pada sektor pendidikan, sejumlah negara terpaksa menutup sementara lembaga-lembaga pendidikan sebagai upaya untuk membendung laju penyebaran pandemi COVID-19 ini. Akibatnya, lebih dari $60 \%$ populasi siswa di dunia harus menanggung dampaknya. Berdasarkan data real time yang dirilis oleh UNESCO melalui Global Monitoring of School Closures Caused by Covid-19 pada minggu pertama bulan Juli ini, lebih dari satu milyar anak usia sekolah di 143 negara terpaksa belajar dari rumah, termasuk lebih dari 68 juta pelajar di Indonesia Pada bulan Maret lalu, Kementerian Pendidikan dan Kebudayaan Republik Indonesia telah mengeluarkan kebijakan untuk menutup sementara seluruh lembaga pendidikan dan meniadakan seluruh kegiatan tatap muka di lembaga pendidikan pada semua jenjang pendidikan. Selama massa pandemi, seluruh kegiatan pembelajaran dilakukan secara daring. Penyampaian materi ajar, penugasan, diskusi, hingga evaluasi dilakukan secara daring dengan memanfaatkan berbagai platform aplikasi daring.

Kebijakan daring diatur melalui Surat Edaran Kemendikbud No. 4 Tahun 2020 dan Surat Edaran Kemendikbud Nomor 15 Tahun 2020 tentang Pedoman Penyelenggaraan
Belajar dari Rumah dalam Masa Darurat Penyebaran Covid-19. Setidaknya terdapat tiga pokok kebijakan pembelajaran daring tersebut, pertama, memastikan pemenuhan hak peserta didik untuk mendapatkan layanan pendidikan selama darurat COVID-19; Kedua, kegiatan pembelajaran dilaksanakan untuk memberikan pengalaman belajar yang bermakna bagi peserta didik, tanpa terbebani tuntutan menuntaskan seluruh capaian kurikulum. Ketiga, aktivitas dan tugas pembelajaran dapat bervariasi antar siswa, sesuai minat dan kondisi masing-masing, termasuk mempertimbangkan kesenjangan akses /fasilitas belajar di rumah.

Sistem pembelajaran daring berbasis teknologi informasi memberikan jaminan keluasan jangkauan yang sangat sesuai untuk berbagai lapisan masyarakat yang dapat diakses di berbagai tempat dan waktu. Istilah daring merupakan akronim dari "dalam jaringan“. Jadi pembelajaran daring adalah salah model pembelajaran online atau dilakukan melalui jaringan internet yang bertujuan untuk memperluas akses pendidikan yang lebih bermutu. Di masa pandemi, kebutuhan untuk memberikan akses pendidikan secara prima kepada populasi yang lebih luas dan beragam melalui cara-cara yang lebih fleksibel, efektif dan bahkan murah telah mendorong perubahan sistem pendidikan . Melalui pembelajaran daring ini diharapkan dapat mempermudah setiap orang untuk terhubung secara online dan dapat mengakses informasi dan pembelajaran dengan cepat dan efektif.

Bates dan Wulf menjelaskan bahwa pembelajaran daring ini memiliki sejumlah manfaat antara lain: 1) Meningkatkan kadar interaksi pembelajaran antara siwa dan guru (enhance interactivity), 2) Memungkinkan 
terjadinya fleksibilitas interaksi pembelajaran, baik tempat maupun waktu (time and place flexibility), 3) Menjangkau siswa semakin luas (potential to reach a global audience), 4) Mempermudah pembaruan dan penyimpanan materi ajar (easy updating of content as well as archivable capabilities).

Sejatinya, masyarakat Indonesia sudah dikenal sebagai masyarakat melek digital. Berdasarkan data Global Digital Report yang dirlis oleh We Are Social pada awal tahun 2020 lalu, jumlah pengguna internet di Indonesia sudah mencapai 175,4 Juta pengguna. Lebih dari 171 juta pengguna internet diantaranya telah memanfaatkan telepon pintar (smartphone) untuk mengakses internet dengan rata-rata durasi waktu akses selama 4 jam menit per hari dari telepon pintar sedangkan rata-rata akses internet dunia hanya 3 jam 22 menit. Lebih jauh, rata-rata durasi akses internet melalui berbagai perangkat adalah 7 jam 59 menit per hari dari berbagai perangkat sementara ratarata durasi akses dunia hanya 6 am 43 menit. Saat ini Indonesia termasuk salah satu Negara dengan pertambahan populasi pengguna internet terbesar di dunia. Indonesia hanya kalah dari India dan Cina. Indonesia berada di peringkat tiga dengan pertumbuhan populasi pengguna internet (internet users) sebesar 17\%. Angka ini sama dengan 25,3 juta pengakses internet baru dalam setahun. Data tersebut mengindikasikan bahwa sebagaian besar masyarakat Indonesia telah terbiasa mengakses internet dengan menggunakan berbagai perangkat digital termasuk telepon pintar dalam durasi waktu yang lama. Apalagi dengan adanya kebijakan pembelajaran daring dari rumah seperti saat ini, tentu intensitas penggunaan telepon pintar ataupun perangkat digital lain untuk akses internet akan lebih sering dilakukan dan dalam durasi yang lama.

Meskipun demikian, implementasi kebijakan untuk tetap menjalankan pendidikan bermutu melalui pembelajaran daring di tiap level jenjang pendidikan bukanlah perkara mudah karena pada kenyataannya model pembelajaran daring ini merupakan suatu model pembelajaran yang belum biasa diiterapkan oleh mayoritas sekolah di Indonesia sebelumnya, utamanya adalah pendidikan dasar

\section{METODE PENELITIAN}

Penelitian ini merupakan penelitian kuantitatif deskriptif untuk mengetahui gambaran persepsi guru terhadap efektivitas pembelajaran daring selama masa pandemi Covid-19 ini. Responden dalam penelitian ini adalah guru-guru MI di wilayah kabupaten Bantul sebanyak 46 orang. Teknik pengumpulan data yang digunakan yakni kuesioner atau angket yang disebarkan kepada informan melalui suvei secara daring (medsos dan surat elektronik). Data hasil survei yang diperoleh kemudian dianalisis menggunakan statistik deskriptif. Analisis data dilakukan dengan model analisis Miles, M. B., \& Huberman, M. melalui tiga tahapan, yaitu reduksi data, display data, serta penarikan dan verifikasi kesimpulan Analisis data merupakan tahap mengumpulkan seluruh informasi yang dibutuhkan dari hasil survei lalu di kelompokkan datanya. Tahap display data merupakan pemaparan data yang diperlukan dalam penelitian dan yang tidak perlu dibuang. Tahap penarikan dan verifikasi kesimpulan adalah tahap interpretasi data penelitian untuk ditarik kesimpulan berdasarkan fenomena yang didapatkan

\section{HASIL PENELITIAN DAN PEMBAHASAN Karakteristik Responden}

Responden penelitian ini adalah guruguru MI/SD di Kabupaten Bantul. Jumlah keseluruhan responden berjumlah 46 orang. Adapun deskripsi rinci tentang responden dapat dilihat pada tabel 1 .

Berdasarkan tabel 1, sebagian besar responden merupakan guru perempuan (82, $86 \%$ ) yang didominasi usia antara 25-34 tahun. Responden merupakan representasi dari guruguru yang mengajar di semua kelas, meskipun demikian, responden tersebesar adalah guruguru yang mengajar di kelas $4(30,00 \%)$ dan kelas $3(25,71 \%)$. 
Tabel 1. Karakteristik Responden

\begin{tabular}{|c|c|c|}
\hline Jenis Kelamin & $\mathbf{n}$ & $\%$ \\
\hline Laki-laki & 8 & $17,14 \%$ \\
\hline Perempuan & 38 & $82,86 \%$ \\
\hline $\mathrm{n}$ & 46 & $100,00 \%$ \\
\hline Usia & $\mathrm{n}$ & $\%$ \\
\hline $25-34$ & 28 & $60,95 \%$ \\
\hline $35-44$ & 14 & $29,52 \%$ \\
\hline $45-54$ & 10 & $9,52 \%$ \\
\hline $\mathrm{n}$ & 46 & $100,00 \%$ \\
\hline Guru Kelas & $\mathbf{n}$ & $\%$ \\
\hline 1 & 6 & $13,33 \%$ \\
\hline 2 & 5 & $10,48 \%$ \\
\hline 3 & 12 & $25,71 \%$ \\
\hline 4 & 14 & $30,00 \%$ \\
\hline 5 & 5 & $11,43 \%$ \\
\hline 6 & 4 & $9,52 \%$ \\
\hline $\mathrm{n}$ & 46 & $100,00 \%$ \\
\hline $\begin{array}{l}\text { Melaksanakan } \\
\text { Pembelajaran Daring }\end{array}$ & $\mathbf{n}$ & $\%$ \\
\hline $\mathrm{Ya}$ & 46 & $100,00 \%$ \\
\hline Tidak & 0 & $0,00 \%$ \\
\hline $\mathrm{n}$ & 46 & $100,00 \%$ \\
\hline $\begin{array}{l}\text { Platform yang } \\
\text { digunakan }\end{array}$ & n & $\%$ \\
\hline Email & 2 & $4,76 \%$ \\
\hline Whatsapp & 16 & $35,24 \%$ \\
\hline Facebook & 2 & $4,76 \%$ \\
\hline Zoom & 7 & $16,19 \%$ \\
\hline Google Classroom & 5 & $11,43 \%$ \\
\hline Microsoft Teams & 0 & $0,00 \%$ \\
\hline Youtube & 8 & $18,10 \%$ \\
\hline Google Form & 2 & $4,76 \%$ \\
\hline LMS & 2 & $4,76 \%$ \\
\hline $\mathrm{n}$ & 46 & $100,00 \%$ \\
\hline Bentuk Pembelajaran & $\mathbf{n}$ & $\%$ \\
\hline Penugasan & 32 & $30,48 \%$ \\
\hline Video Tutorial & 18 & $17,14 \%$ \\
\hline Ceramah & 5 & $4,76 \%$ \\
\hline Latihan Soal & 32 & $30,48 \%$ \\
\hline Quiz & 5 & $4,76 \%$ \\
\hline Lain-lain & 13 & $12,38 \%$ \\
\hline n & 105 & $100,00 \%$ \\
\hline
\end{tabular}

\section{Persepsi Guru Terhadap Pembelajaran di masa Covid-19}

Persepsi terhadap aktivitas pengajaran yang diselenggarakan oleh masing-masing guru dilihat dari sejumlah aspek meliputi persepsi terhadap keterlaksanaan program pengajaran, persepsi terhadap efektivitas aktivitas pengajaran dan persepsi terhadap hambatan aktivitas pengajaran.

Berdasarkan hasil penelitian, selama pandemi Covid-19, semua responden mengaku telah menjalankan pembelajaran secara daring dan hampir sebagain besar responden menyatakan bahwa pembelajaran daring selama BDR telah diselenggarakan secara terstruktur, terorganisasi dan sesuai dengan jadwal yang telah ditetapkan. Kegiatan pengajaran pun telah diselenggarakan sesuai dengan Rencana Pelaksanaan Pembelajaran (RPP) yang telah dibuat sebelumnya. Platform aplikasi yang paling banyak digunakan oleh para guru adalah whatsapp sebanyak 35,24\%, Youtube sebanyak 18,10\%, Zoom Meeting sebanyak $16,19 \%$ dan platform lain sebanyak 30,47\%. Meskipun demikian, pelaksanaan pembelajaran daring dilaksanakan masih disesuaikan dengan kondisi dan situasi yang ada. Sebanyak $56,50 \%$ responden yang mempersingkat waktu pembelajaran, sedangkan $30,40 \%$ responden lainnya tetap melaksanakan kegiatan pengajaran sesuai dengan jadwal.

Pelaksanaan pembelajaran daring memungkinan guru dan siswa melaksanakan pembelajaran secara daring dari rumah masing-masing. Siswa dapat mengakses materi pembelajaran dan mengirim tugas yang diberikan guru tanpa harus bertemu dan tatap muka secara langsung. Tujuan dari pembelajaran daring adalah meminimalisasi kerumunan massa dan kontak fisik di sekolah. Acuan utama penyelenggaraan pembelajaran daring di masa pandemi Covid-19 adalah Surat Edaran Kemendikbud No.4 Tahun 2020 dan Kurikulum Darurat Dirjen Pendis Kemenag RI yang tertuang dalam keputusan Direktur Jenderal Pendidikan Islam Nomor 2791 tahun 2020 Tentang Panduan Kurikulum Darurat pada Madrasah, Kedua produk kebijakan tersebut merupakan salah satu upaya pemerintah untuk memastikan hak setiap anak untuk tetap mendapatkan layanan pendidikan selama masa pandemi COVID-19.

Jika merujuk kepada Panduan Kurikulum Darurat yang telah dikeluarkan oleh Dirjen 


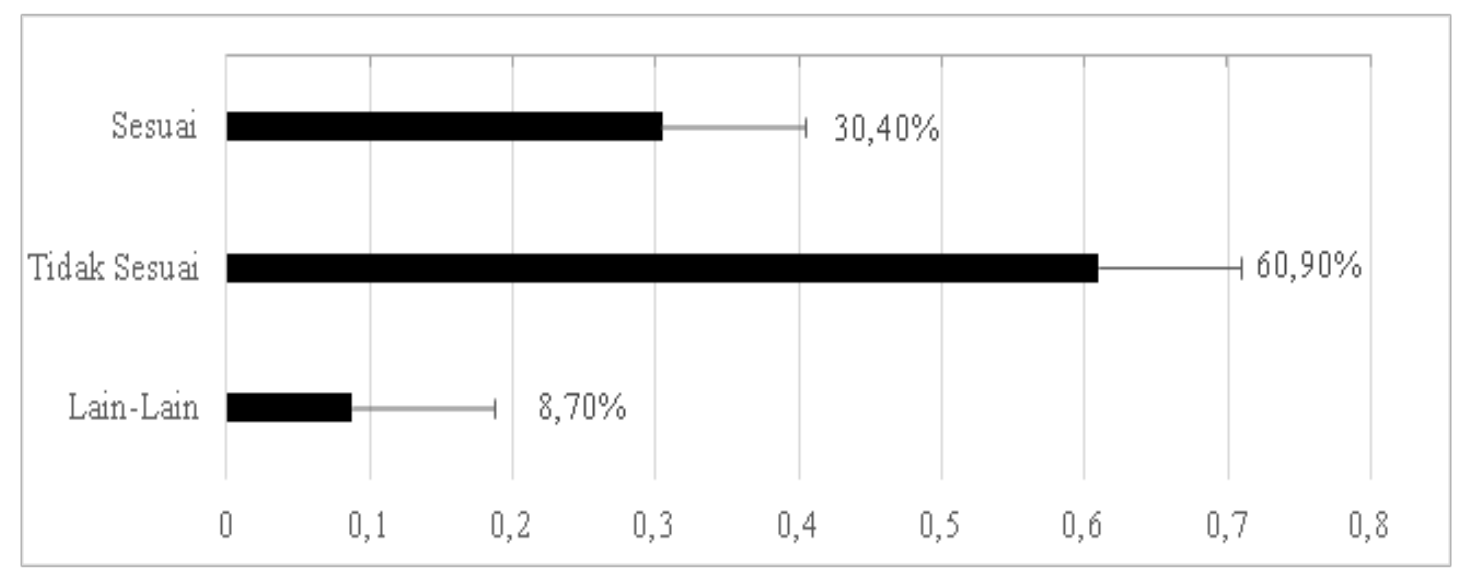

Gambar 1. Persentase Persepsi Guru terhadap Kesesuaian Pengajaran dengan Rencana Pelaksanaan Pembelajaran (RPP)

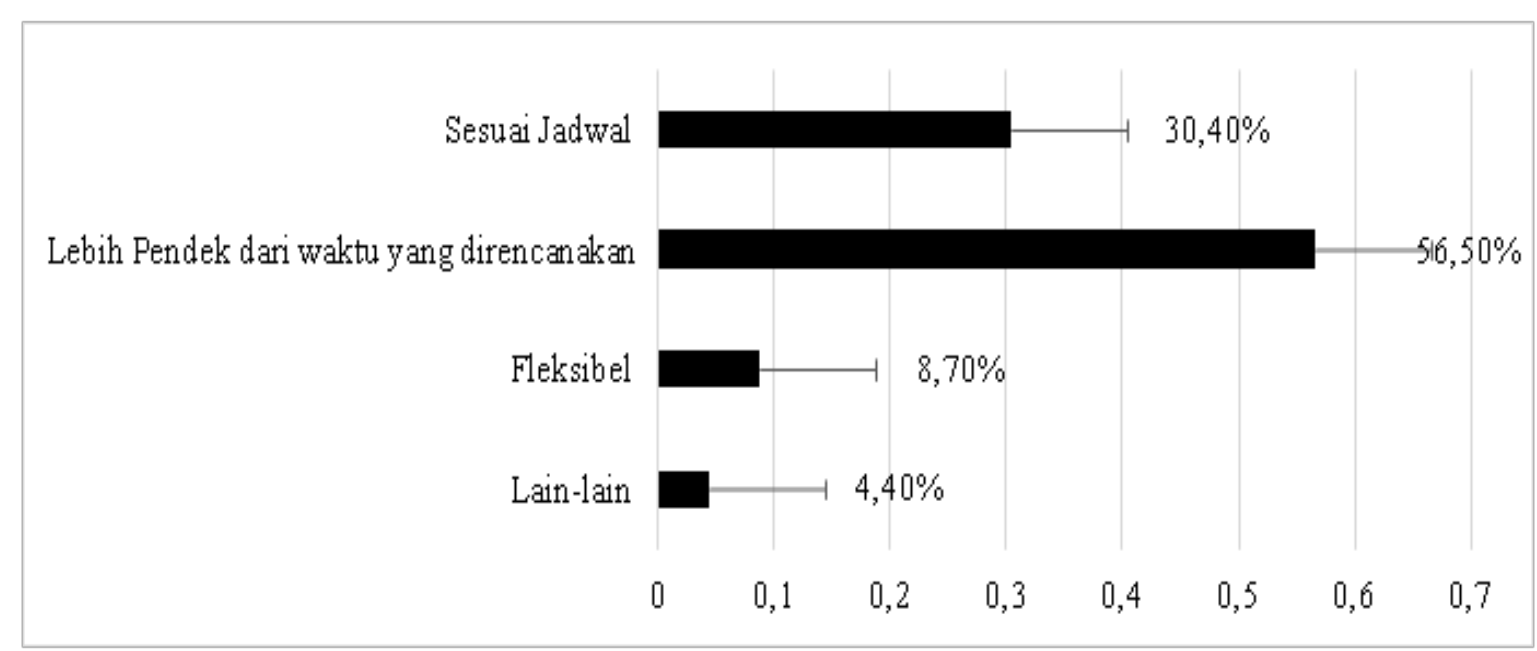

Gambar 2. Persentase Persepsi Guru terhadap Durasi Pelaksanaan Pengajaran Daring

Terstruktur, Terorganisasi dan Sesuai Jadwal/Kalender Akademik

Tidak terstruktur, terorganiasi dan sesuai Jadwal/Kalender Akademik

Terstruktur, Terorganisasi dan tapi tidak sesuai Jadwal/Kalender Akademik

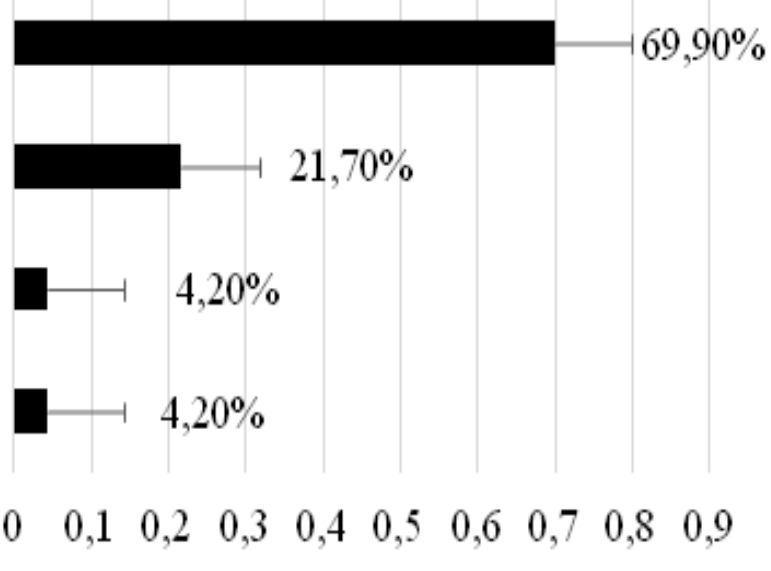

Gambar 3. Persentase Persepsi Guru terhadap Keterlaksanaan Pengajaran 


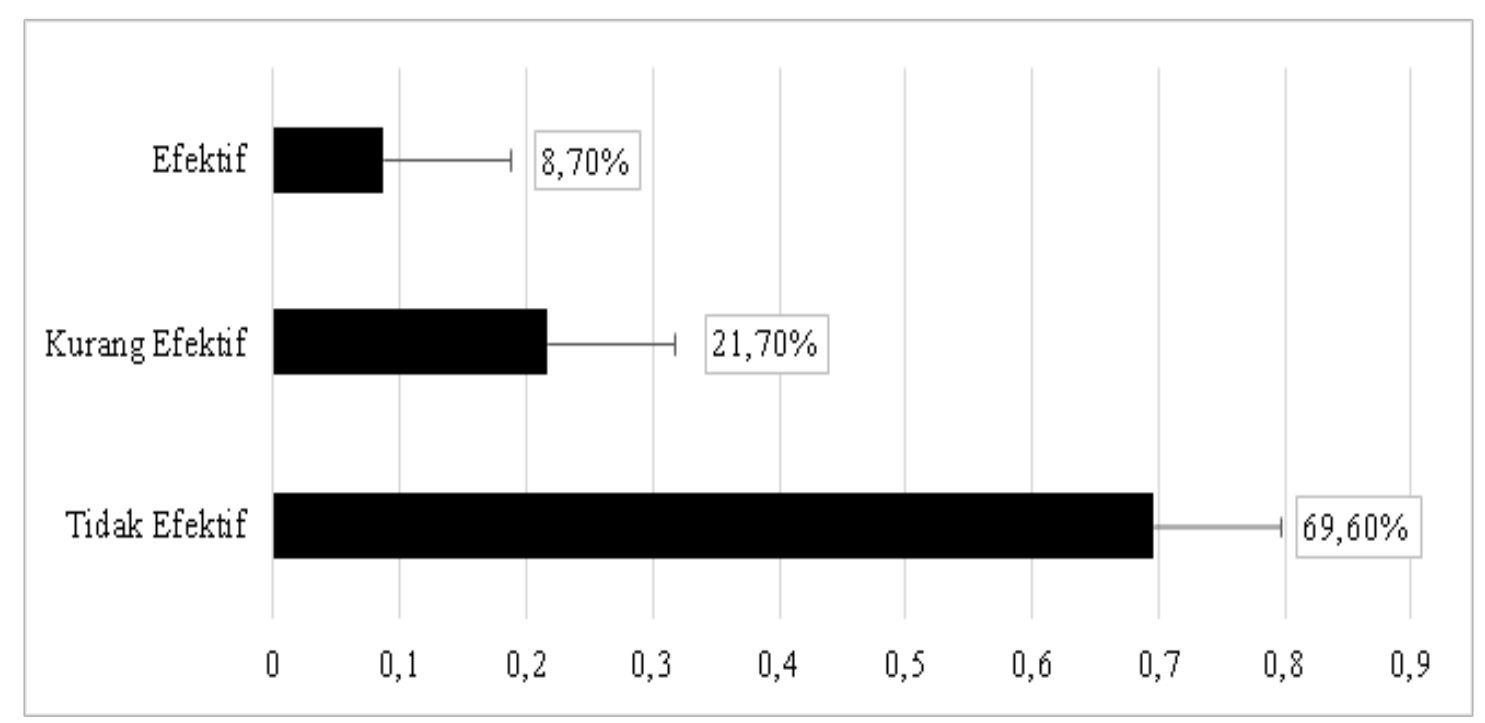

Gambar 4. Persentse Persepsi Guru terhadap tingkat Efektivitas Pembelajaran Daring

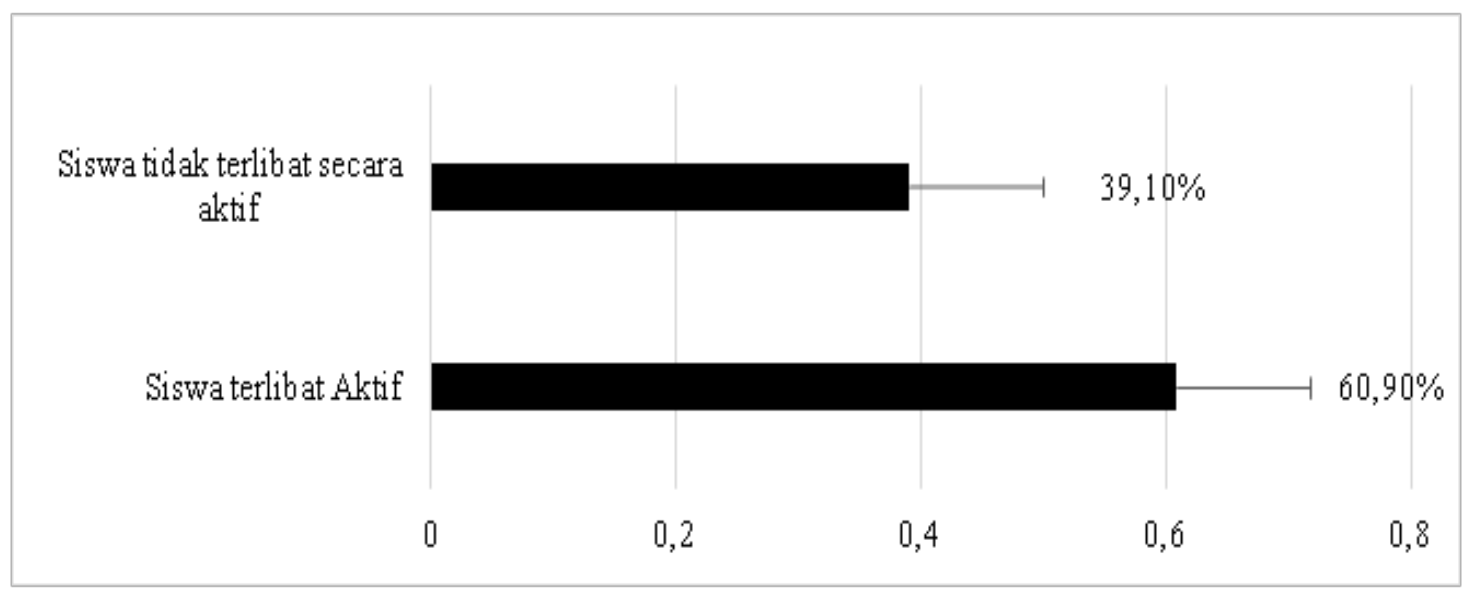

Gambar 5. Persentase Persepsi Guru terhadap Keterlibatan Siswa

Pendis Kemenag RI, upaya pemenuhan kewajiban pemberian layanan pendidikan kepada anak selama masa pandemi ini telah dilaksanakan dengan baik oleh mayoritas guru dan Madrasah meskipun melalui sejumlah modifikasi. Hal ini sudah sesuai denganPanduan Kurikulum Darurat yang menyatakan bahwa "Semua aspek yang berkenaan dengan perencanaan pembelajaran, kegiatan pembelajaran dan penilaian hasil belajar disesuaikan dengan kondisi darurat yang terdapat dan dirasakan oleh setiap satuan pendidikan madrasah. Mempertimbangkan kondisi darurat setiap daerah dan madrasah berbeda, maka implementasi kurikulum darurat setiap satuan pendidikan bisa berbeda- beda sesuai dengan kondisi dan kebutuhan masing-masing".

Sedangkan terkait tingkat efektivitas pengajaran yang diselenggarakan, para guru beranggapan bahwa masih banyak kendala yang dihadapi selama pembelajaran daring ini. Sebagian besar responden mengungkapkan bahwa kegiatan pembelajaran daring selama ini dianggap tidak efektif $(69,60 \%)$ dan hanya sedikit responden $(8,70 \%)$ yang menyatakan efektif, meskipun tingkat keterlibatan siswa dalam pembelajaran daring ini cukup tinggi $(69,90 \%)$.

Menurut sejumlah responden, ketidakefektifan pembelajaran daring selama 
Tabel 2. Kendala Pembelajaran Daring

\begin{tabular}{|c|c|}
\hline Jenis Kendala & Rincian \\
\hline $\begin{array}{l}\text { Sarana dan Prasarana yang belum } \\
\text { memadai }\end{array}$ & $\begin{array}{l}\text { 1. Keterbatasan/ ketiadaan Kuota internet } \\
\text { 2. Keterbatasan/ ketiadaan alat komunikasi yang memadai } \\
\text { 3. Keterbatasan/ ketiadaan Jaringan/sinyal provider tertentu di sejumlah } \\
\text { wilayah }\end{array}$ \\
\hline $\begin{array}{l}\text { Wali/orang tua tidak bisa } \\
\text { mendampingi secara optimal }\end{array}$ & $\begin{array}{l}\text { 1. Orang tua/ wali siswa bekerja } \\
\text { 2. Siswa belum siap belajar mandiri, terutama siswa kelas rendah } \\
\text { 3. Sejumlah siswa berada di pondok pesantren }\end{array}$ \\
\hline $\begin{array}{l}\text { Target tujuan Pembelajaran yang } \\
\text { sulit dicapai }\end{array}$ & $\begin{array}{l}\text { 1. Materi kelas rendah sulit untuk didaringkan } \\
\text { 2. Monitoring dan penilaian pembelajaran hanya berbasis penugasan }\end{array}$ \\
\hline asaan IT guru dan siswa rend & \\
\hline
\end{tabular}

program BDR ini disebabkan oleh sejumlah kendala. Rincian kendala yang dikemukakan oleh para responden dapat dilihat pada tabel 2.

Lebih jauh, sejumlah responden juga memperoleh keluhan dari sejumlah siswa terkait kesehatan siswa selama mengikuti pembelajaran daring. Setidaknya ada 13,00\% siswa yang mengeluh secara langsung terkait masalah kesehatan mereka selama mengikuti pembelajaran daring.

Selain itu, sejumlah orang tua/ wali siswa juga menyampaikan keluhan kepada para responden terkait penyelenggaraan pembelajaran daring selama ini.

Proses adaptasi perubahan paradigma dan pendekatan pembelajaran yang baru ini menimbulkan "kegagapan" di setiap lini dan masih membutuhkan waktu. Tidak hanya madrasah dan guru, tetapi juga siswa dan orang tua/wali. Temuan penelitian ini telah memberikan gambaran bahwa meskipun mayoritas guru beranggapan bahwa program pembelajaran telah dilaksanakan dengan baik, namun hal tersebut belum bisa menjamin efektifvitas pembelajaran daring ini. Interaksi yang terjalin antara guru-siswa-orang tua/ wali dalam pembelajaran tatap muka belum bisa tergantikan secara efektif dengan pembelajaran daring ini. ${ }^{1}$ telah memprediksi adanya kesenjangan antara harapan ideal dan kenyataan dalam mengintegrasikan interaksi pembelajaran sebagai bagian dari aktivitas online dalam pembelajaran ini.

${ }^{1}$ Sungae et al., (2014)
Temuan ini juga memperkuat pernyataan dari menyatakan bahwa sejumlah kendala yang ada disebabkan karena ketidaksiapan siswa, guru, orang tua dan institusi pendidikan untuk segera beradaptasi dengan budaya belajar jarak jauh melalui daring ini karena selama sistem belajar yang dilaksanakan adalah melalui tatap muka. ${ }^{2}$ Alhasil, sejumlah siswa menjadi bosan, malas dan jenuh dengan pembelajaran daring dan melampiaskan dengan banyak bermain dan menjadi candu dengan gawai. Orang tua juga merasa menjadi "korban" dari pembelajaran daring ini karena harus menyisihkan waktu di tengah berbagai kesibukan dan pekerjaan untuk mendampingi anak mereka untuk belajar dan mengerjakan berbagai macam tugas dan bahkan harus menyelesaikan sejumlah tugas yang semestinya menjadi tanggung jawab anak mereka, serta mengalokasikan lebih banyak uang belanja untuk membeli kuota internet. Pembelajaran daring tidak dapat dilakukan jika sekolah, siswa maupun orang tua tidak memiliki capital yang memadai dan mengelola capital tersebut secara baik. Menurut Arifin pembelajaran daring tidak akan dapat berlangsung ketika guru dan siswa sama-sama memiliki keterbatsan untuk mengakses perangkat dan jaringan internet secara memadai ${ }^{3}$.

Penguatan kemampuan guru untuk dapat mengelola pembelajaran daring menjadi lebih interaktif, bermutu dan efektif

${ }^{2}$ Purwanto et al., (2020)

${ }^{3}$ Arifin, "Respon Siswa Terhadap Pembelajaran Dalam Jaringan Masa Pandemi Chovid-19 Di Madrasah Aliyah Al-Amin Tabanan." 


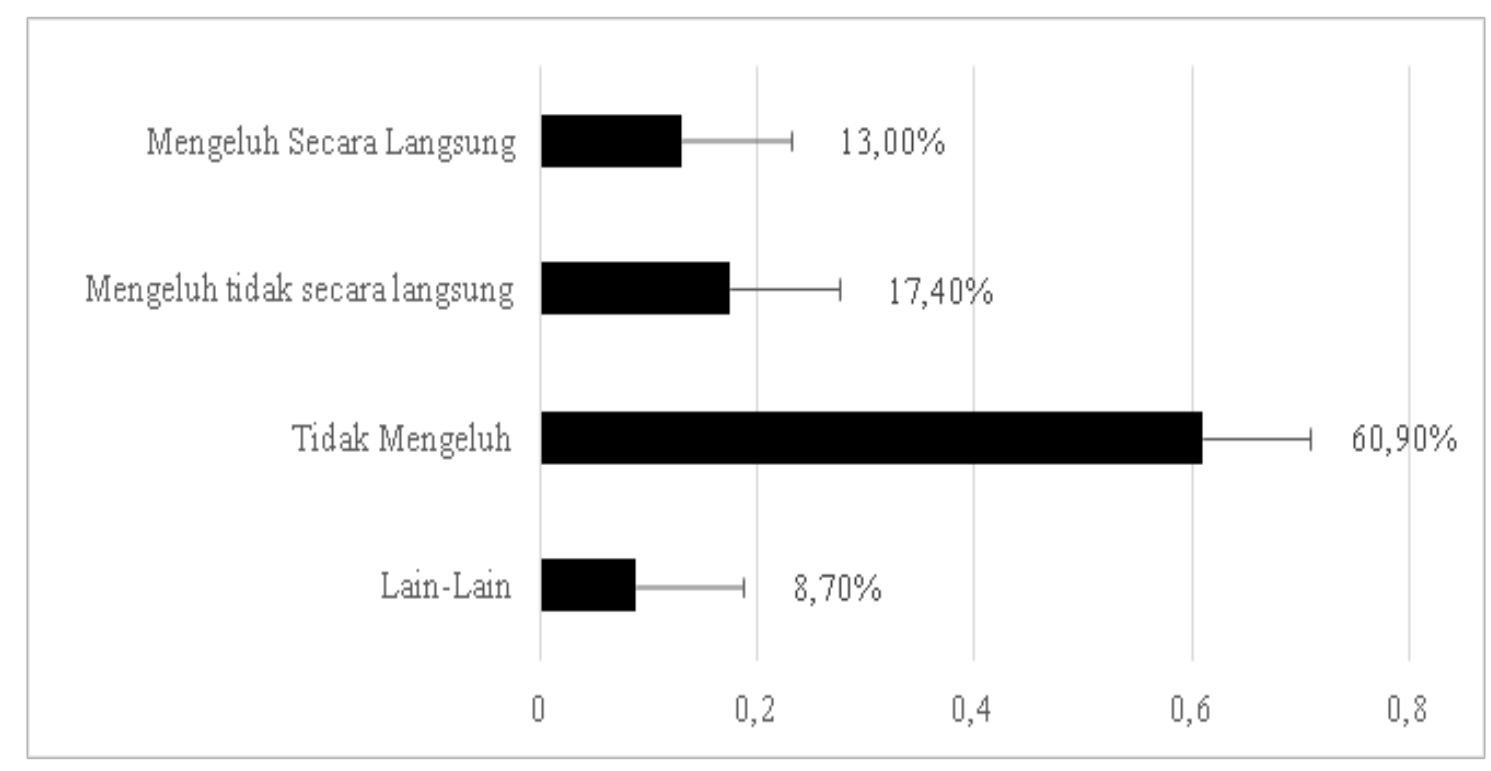

Gambar 6. Persentase Keluhan Kesehatan Siswa

Tabel 3. Keluhan orang tua/wali siswa yang disampaikan ke guru

\begin{tabular}{cl}
\hline No & \multicolumn{1}{c}{ Jenis Keluhan } \\
\hline 1 & Sebagian orang tua/wali merasa \\
& kesulitan membagi waktu dan kurang \\
& sabar mendampingi anak belajar dari \\
& rumah \\
2 & Sebagian orang tua/wali mengeluhkan \\
& anak mereka menjadi malas belajar, \\
& bosan dengan rutinitas, jenuh dan \\
& kecanduan gawai, kurang disiplin dan \\
& banyak bermain. \\
3 Sebagian orang tua/wali mengeluhkan & jumlah tugas yang dibebankan \\
& Sebagian orang tua/wali merasa \\
& kesulitan terkait beban belanja kuota \\
& yang semakin meningkat
\end{tabular}

menjadi sebuah kebutuhan untuk saat ini. ${ }^{4}$ mengungkapkan bahwa terdapat tiga hal yang berkaitan dengan pengembangan pembelajaran daring, yakni konten, kanal, infrastruktur atau teknologi informasi (Tl). Lebih jauh, Mustofa juga berpendapat bahwa perlu adanya tambahan persyaratan lain, seperti: (a) pihak penyelenggara kegiatan e-learning, (b) mindset positif pengajar dan siswa dalam fungsi utama

${ }^{4}$ Mustofa et al., (2019) internet, (c) desain sistem proses belajar yang bisa dipelajari oleh semua siswa, (d) adanya proses evaluasi dari rangkaian proses belajar siswa, dan (e) mekanisme feedback dari pihak penyelenggara. Sejatinya, pembelajaran daring siswa memiliki keleluasaan waktu belajar. Siswa dapat belajar kapanpun dan di manapun. Siswa juga dapat berinteraksi dengan guru baik secara synchronous - interaksi belajar pada waktu yang bersamaan seperti dengan menggunakan video converence, telepon atau live chat, maupun asynchronous - interaksi belajar pada waktu yang tidak bersamaan melalui kegiatan pembelajaran yang telah disediakan secara digital. Lebih jauh, ${ }^{5}$ mengungkapkan bahwa guru dan institusi pendidikan perlu memperhatikan sejumlah faktor yang dapat menciptakan pengalaman belajar yang menarik selama pembelajaran daring yakni dengan menciptakan dan memelihara lingkungan belajar yang positif; membangun komunitas belajar; memberikan umpan balik yang konsisten secara tepat waktu; dan menggunakan teknologi yang tepat untuk mengirimkan konten yang tepat

${ }^{5}$ Misha and Fredrick, "Strengthening Student Engagement: What Do Students Want in Online Courses?" 


\section{KESIMPULAN}

Selama program Belajar dari Rumah (BDR) diselenggarakan, semua MI di wilayah Kabupaten Bantul telah melaksanakan pembelajaran daring dengan mengacu pada aturan dan kebijakan yang berlaku. Meskipun demikian, persepsi dari sebagian besar guruguru tersebut pembelajaran daring di masa pandemi Covid-19 ini belum berjalan secara efektif $(69,60 \%)$. Hal ini dipengaruhi oleh sejumlah faktor mulai dari keterbatasan saranaprasarana, kesiapan orang tua/ wali dalam melakukan pendampingan kepada anak pada saat belajar dari rumah, dan sebagian guru belum mampu merespon dan beradaptasi dengan mode pembelajaran daring karena keterbatasan penguasaan IT sehingga materi ajar dan proses pembelajaran yang dilaksanakan belum sesuai dengan tujuan pembelajaran yang telah ditetapkan.

\section{DAFTAR PUSTAKA}

Arifin, Ahmad Syamsul. "Kecenderungan Global Pendidikan Tinggi Dan Pergeseran Paradigma Reformasi Pendididikan Tinggi Pada \nstitusi Pendidikan Tinggi Keagamaan Islam." LITERASI (Jurnal Ilmu Pendidikan) 6, no. 2 (2015): 135. https://doi. org/10.21927/literasi.2015.6(2).135-154.

Arifin, Haris Nursyah. "Respon Siswa Terhadap Pembelajaran Dalam Jaringan Masa Pandemi Chovid-19 Di Madrasah Aliyah Al-Amin Tabanan." Dk 53, no. 9 (2015): 1689-99. https://doi.org/10.1017/ CBO9781107415324.004.

Bates, Tony. "The Impact of Technological Change on Open and Distance Learning." Distance Education 18, no. 1 (2006): 93-109. https:// doi.org/10.1080/0158791970180108.

Direktorat Jenderal Pendidikan Islam. Keputusan Dirjen Pendis No. 2791 Tahun 2020 Panduan Kurikulum Daruratpada Madrasah, 21 Direktorat Jenderal Pendidikan Islam § (2020).

Misha, Chakraborty, and Muyia Nafukho Fredrick. "Strengthening Student Engagement: What Do Students Want in Online Courses?"
European Journal of Training and Development 38, no. 9 (January 1, 2014): 782-802. https://doi.org/10.1108/EJTD-112013-0123.

Mustofa, Mokhamad Iklil, Muhammad Chodzirin, Lina Sayekti, and Roman Fauzan. "Formulasi Model Perkuliahan Daring Sebagai Upaya Menekan Disparitas Kualitas Perguruan Tinggi." Walisongo Journal of Information Technology 1, no. 2 (2019): 151. https://doi.org/10.21580/ wjit.2019.1.2.4067.

Purwanto, Agus, Rudy Pramono, Masduki Asbari, Priyono Budi Santoso, Laksmi Mayesti Wijayanti, Chi Hyun Choi, and Ratna Setyowati Putri. "Studi Eksploratif Dampak Pandemi COVID-19 Terhadap Proses Pembelajaran Online Di Sekolah Dasar." EduPsyCouns: Journal of Education, Psychology and Counseling 2, no. 1 (2020): 1-12. https://ummaspul.e-journal. $\mathrm{id} /$ Edupsycouns/article/view/397.

RI, Kementerian Pendidikan dan Kebudayaan. Surat Edaran Menteri Pendidikan dan Kebudayaan RI No.4 Tahun 2020 (2020).

"School Closures Caused by Coronavirus (Covid-19)." Accessed September 23, 2020. https://en.unesco.org/covid19/ educationresponse/.

"Social, Digital and Mobile in Indonesia - We Are Social UK - Global Socially-Led Creative Agency." Accessed September 23, 2020. http://wearesocial.com/uk/blog/2011/12/ social-digital-mobile-indonesia.

Sugiyono, Prof. "Metodologi Penelitian Kuantitatif Kualitatif Dan R\&D." Alpabeta, Bandung, 2011.

Sungae, Yoo, Jeong Kim Hye, and Young Kwon So. "Between Ideal and Reality: A Different View on Online-Learning Interaction in a Cross-National Context." Journal for Multicultural Education 8, no. 1 (January 1, 2014): 13-30. https://doi.org/10.1108/ JME-04-2013-0018.

Wearesocial. "Digital in 2020," 2020. https:// wearesocial.com/digital-2020. 